\title{
NEW RECORDS OF THE INVASIVE AMPHIPOD ECHINOGAMMARUS ISCHNUS (STEBBING, 1899) IN CROATIA
}

\author{
Krešimir Žganec ${ }^{1 *}$, Renata ĆuK ${ }^{2}$ \& Svjetlana Dekić ${ }^{3}$ \\ ${ }^{1}$ University of Zadar, Department of Teacher Education Studies in Gospić, HR-53000 Gospić \\ ${ }^{2}$ Hrvatske Vode, Central Water Management Laboratory, Ulica grada Vukovara 220, HR-10000 Zagreb \\ ${ }_{3}^{3} J u r j a$ Križanića 10, HR-44000 Sisak
}

Žganec, K., Ćuk, R. \& Dekić, S.: New records of the invasive amphipod Echinogammarus ischnus (Stebbing, 1899) in Croatia. Nat. Croat., Vol. 24, No. 2., 247-254, Zagreb, 2015.

The Ponto-Caspian alien and invasive amphipod, Echinogammarus ischnus (Stebbing, 1899), was found in Croatia at three sites in the lower course of the Drava River and at three sites in the Danube River (Batina, Borovo and Ilok). The most upstream site in the Drava where the species was found is a locality near Donji Miholjac, approximately $82 \mathrm{~km}$ upstream from the confluence with the Danube River. At this site as well as at two downstream sites (Osijek and Belišće) in Drava it was found together with the dominant invasive amphipods Dikerogammarus villosus and Chelicorophium curvispinum, while at the Donji Miholjac site it also co-occurs with two native species, Gammarus fossarum and G. roeseli.

Key words: Amphipoda, Gammaridae, invasive species, large rivers, Danube, Drava

Žganec, K., Ćuk, R. \& Dekić, S.: Nalazi invazivnog rakušca Echinogammarus ischnus (Stebbing, 1899) u Hrvatskoj. Nat. Croat., Vol. 24, No. 2., 247-254, Zagreb, 2015.

Ponto-kaspijski strani i invazivni rakušac Echinogammarus ischnus (Stebbing, 1899), pronađen je u Hrvatskoj u donjem toku rijeke Drave i na tri lokaliteta u Dunavu (Batina, Borovo i Ilok). Najuzvodnija postaja na kojoj je nađen u Dravi, kod mjesta Donji Miholjac, udaljena je otprilike $82 \mathrm{~km}$ od ušća u Dunav. Na toj, kao i na dvije nizvodne postaje (Osijek i Belišće) u Dravi, zabilježen je zajedno s druge dvije invazivne vrste rakušaca Dikerogammarus villosus i Chelicorophium curvispinum, dok na postaji kod Donjeg Miholjca uz ove dvije dominantne strane vrste dolazi zajedno s još dvije autohtone vrste Gammarus fossarum i G. roeseli.

Ključne riječi: Amphipoda, Gammaridae, invazivna vrsta, velike rijeke, Dunav, Drava

\section{INTRODUCTION}

Alien and invasive amphipods, mostly originating from the Ponto-Caspian Basin, have been spreading throughout European freshwaters during the last two centuries. This rapid range extension has been facilitated by inter-basin canal connections, river ship traffic and many different means of unintentional introduction as well as by intentional introductions (JAzDzewski, 1980; Holdich \& PöcKL, 2007). Since the Danube was connected with the Rhine through the Main-Danube Canal, and especially after the reopening of this canal in 1992, this became the most important migration route for Ponto-Caspian species' range extension to the west, known as the South European corridor (BIJ DE VAATE et al., 2002). Rivers of the Danube catchment drain 62\% of Croatian territory, with the largest tributaries the Drava and Sava Rivers, and the Danube at 


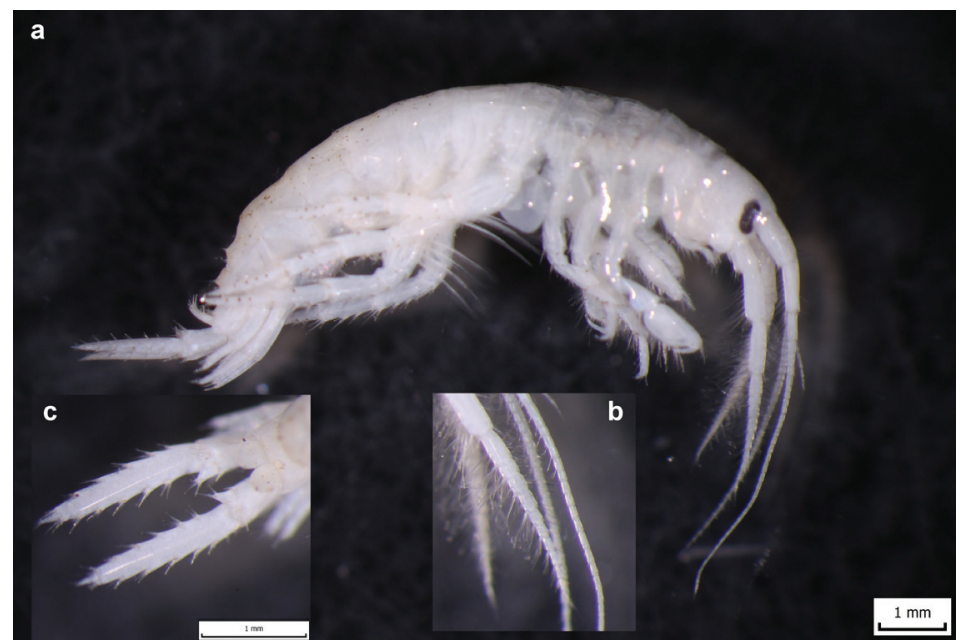

Fig. 1. a) Male specimen of Echinogammarus ischnus from the site Drava-Osijek sampled on $13^{\text {th }}$ February $2015 ; b$ ) detail of flagellum of antenna with characteristic long, curly and abundant setation on second antenna; c) third uropods (U3) and telson viewed from above.

the easternmost border of Croatia with Serbia. Five alien amphipods, Dikerogammarus villosus, D. haemobaphes, D. bispinosus, Obesogammarus obesus and Chelicorophium curvispinum are known to be present in large rivers of Croatia, their distribution being established in a previous study (ŽGANEC et al., 2009).

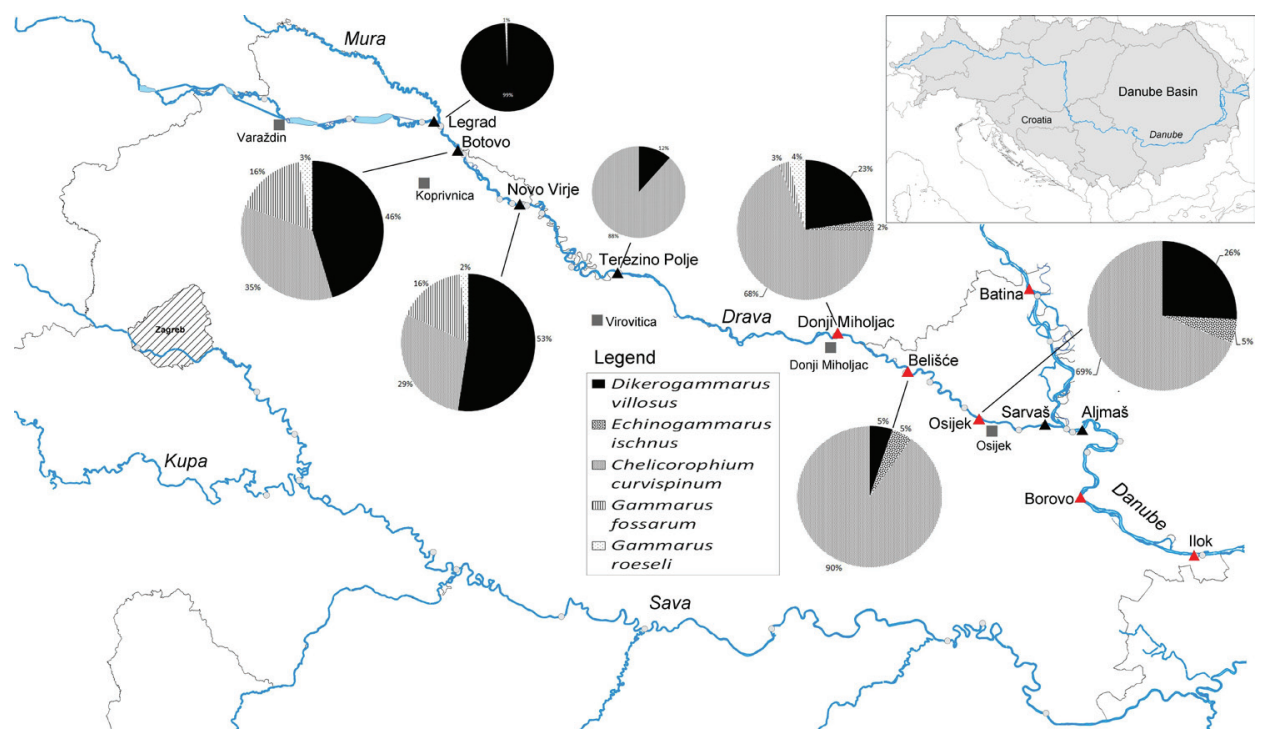

Fig. 2. Map of all study sites sampled in 2015 in Danube and Drava (triangles) and the sites in Sava, Drava and Danube sampled in 2007 and 2008 from ŽGANEC et al. (2009) (grey circles). Red triangles represent sites where Echinogammarus ischnus was found in 2015. 
The species Echinogammarus ischnus (Stebbing, 1899) (syn. Chaetogammarus ischnus) originates from the rivers of Ponto-Caspian Basin. It has migrated to Western Europe through Central and Southern European corridors (JAzDzewsKi, 1980; Bij De VAATE et al., 2002; CRISTESCU et al., 2004). Morphologically, this species is easily recognizable (Fig. 1) because of the relatively small size (11 mm of total length in males), large eyes (typical for the genus Echinogammarus), the abundant curly setation of its second antenna, very short telson lobes, third uropod without seta and only with spines (Fig. 1) and characteristic setation of mandibule palp, a combination which is unique in the genus Echinogammarus (PINKSTER, 1993).

\section{MATERIALS AND METHODS}

Quantitative samples $(n=20)$ were collected at eight sites along the Drava River in February 2015 and at four sites in the Danube in July 2015 (Fig. 2) using hand nets (mesh size $500 \mu \mathrm{m}$ ) over an area of $0.0625 \mathrm{~m}^{2}$ in a shallow bank area. Samples were collected from all available types of substrate, taking into consideration the relative contribution of each microhabitat type. The number of samples from each substrate/microhabitat type corresponds to the relative contribution of a particular microhabitat to the substrate of the assessed river reach $(5 \%=1$ sample) (HRN EN 16150). Samples were fixed with $96 \%$ alcohol. In the laboratory, amphipods were separated from the sediment, organic detritus and other invertebrates and stored in $75 \%$ alcohol for later identification. Amphipods were identified using the keys of CăRĂUşu et al. (1955), KARAman \& Pinkster (1977a, b, 1987), Pinkster (1993) and Eggers \& MArtens (2001). A GPS receiver was used for the geocoding of field observations on the spot, and Gauss-Krüger coordinates were determined for each site. Data were mapped using Diva-Gis program packet.

\section{RESULTS}

Echinogammarus ischnus was found at three of the eight sites in the lower course of Drava and at three of the four sites in the Croatian section of the Danube (Fig. 2). In the Danube it was found at Batina (river kilometre-rkm 1424, 8 specimens), Borovo (rkm 1336, 2 specimens) and at Ilok (rkm 1300, 5 specimens). In the Drava it was found upstream of the town of Osijek, approximately $24 \mathrm{~km}$ upstream from the confluence with Danube (5 specimens), in Belišće (rkm 56, 8 specimens) and at the most upstream site, Donji Miholjac (rkm 82, 2 specimens). At the sites Osijek and Belišće the focal species was found together with Dikerogammarus villosus and Chelicorophium curvispinum. Echinogammarus ischnus had a relative abundance of 5\% at both sites. At the site Donji Miholjac two native species, Gammarus fossarum and G. roeseli, were found together with the former three alien species; and E. ischnus had a relative abundance of 2\% (Fig. 2). Interestingly, amphipods were not found at the most downstream site, Drava-Sarvaš, $12 \mathrm{~km}$ downstream of Osijek, i.e. $5 \mathrm{~km}$ upstream from the confluence with the Danube River.

The density of E. ischnus in the Danube was very similar at the three sites and ranged from 4.8 to 6.7 ind. $\mathrm{m}^{-2}$, with a similar relative abundance of 2.4 to $2.8 \%$ in total number of amphipods collected at each site. At the sites Batina and Ilok most samples were collected on embankments made of large stones, while at two other sites they were collected mostly on sand and mud substrate. In the Drava, density decreased in the upstream direction from 24 ind. $\mathrm{m}^{-2}$ in Osijek to 1.6 ind. $\mathrm{m}^{-2}$ in Donji Miholjac. At three sites where samples were collected in the Drava, the substrate was mostly sand (90-95\%) and mud 


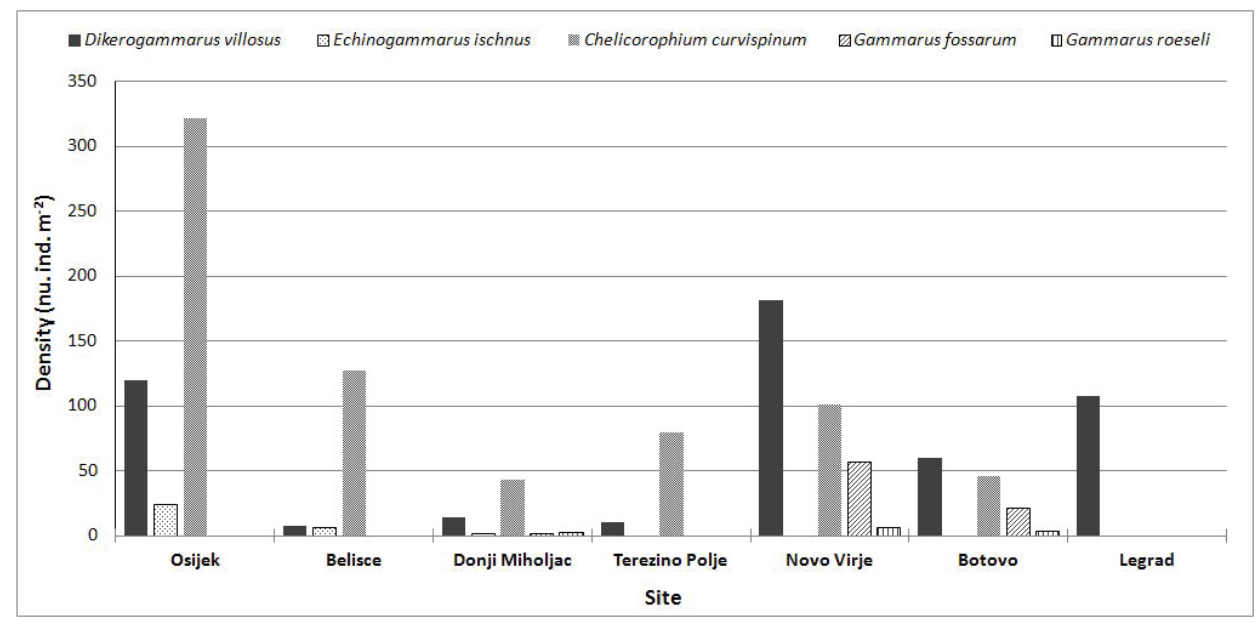

Fig. 3. Densities of all amphipod species at seven sites in Drava in February 2015.

(5\%) and most of the replicate samples (18-19) were collected on these types of substrate. Chelicorophium curvispinum had the highest density at four downstream sites in Drava and $D$. villosus was the second most abundant amphipod at these sites (Fig. 3). At upstream sites Novo Virje, Botovo and Legrad, D. villosus was the most abundant species. The relation between species densities of two alien and two native amphipods was the same at the sites Novo Virje and Botovo. Interestingly, native species, Gammarus fossarum and G. roeseli, were found at three and four sites, respectively, co-occurring with alien amphipods. Density of G. fossarum ranged from 1.6 ind. $\mathrm{m}^{-2}$ at Donji Miholjac to 56.6 ind. $\mathrm{m}^{-2}$ at Novo Virje, while G. roeseli was less abundant $\left(0.8-6.9\right.$ ind. $\left.\mathrm{m}^{-2}\right)$ but it was found at four sites (site Legrad: $1 \%$ or 0.8 ind. $\mathrm{m}^{-2}$ not visible on Fig. 3).

\section{DISCUSSION AND CONCLUSIONS}

Echinogammarus ischnus (syn. Chaetogammarus ischnus) originates from the rivers of the Ponto-Caspian Basin, the lower Volga and the Danube River Delta (CARAusu et al., 1955; Birštejn \& Romanova, 1968), and the Dnieper River Delta (JAZDZEwsKi, 1980). It migrated to Western Europe from the Dnieper River via the Pripet-Bug canal system, which connects to the Vistula River in Poland (Konopacka \& JAsIOnOwSKA, 1995), which is known as Central European corridor (BIJ De VAATE et al., 2002). Through this corridor it advanced all the way to the North Sea and the Baltic Sea (JAZDZEwsKI, 1980). In the Rhine (The Netherlands) it was discovered in the early 1990s (SchöLl, 1990; VAN Den BRINK et al., 1993). The species also managed to cross the Atlantic by ship ballast water and it was discovered in North America in the Great Lakes basin in 1995 (WITT et al., 1997). The rapid range extension of this invasive species along natural and artificial watercourses is well documented in both Europe (JAZDZEwsKI, 1980) and North America (KANG, 2003).

In the Danube it had dispersed up to the Slovakian section, more than $1900 \mathrm{~km}$ upstream from the mouth, by the second half of $20^{\text {th }}$ century (JAZDZEWSKI, 1980). KARAMAN (1953) reports its findings in the Serbian section of Danube (Smederevo, downstream from Belgrade). In the samples collected in 1961 and 1962 at ten sites along the Serbian 
section of the Danube (rkm 1092-1179), PLJAKić (1965) established E. ischnus and Obesogammarus obesus to be the most frequent and dominant species among six recorded amphipod species. However, some more recent studies of the macroinvertebrate communities of Croatian and Serbian section of Danube failed to detect its presence in the Danube (PAunović et al. 2007), while other studies report its presence in the Serbian part of Danube (PAunović et al., 2010). However, in the most recent study Borza et al. (2015) reported findings of the species in the Croatian section of the Danube. Based on these and our data we assume that E. ischnus was more abundant in the Danube in the past, while now has low abundance and it is therefore difficult to detect. It is possible that Dikerogammarus villosus and Chelicorophium curvispinum, which are now the dominant amphipods in the Danube (ŽGANEC et al., 2009; Borza et al., 2015), have caused the decline of $E$. ischnus. The decline of E. ischnus observed in the lower Rhine was probably facilitated by the mass abundance of $C$. curvispinum, which probably reduced the colonization success of $E$. ischnus, a lithophilic dweller, by covering the solid substrates in the river with mud tubes (BIJ De VAATE et al., 2002). Although JAzDZEwsKi (1980) assumed that E. ischnus entered the lower reaches of the Sava and Drava, it was not found in Croatian sections of these rivers before (ŽGANEC et al., 2009). A previous study failed to detect $E$. ischnus in the lower course of the Drava probably because it was still rare and sampling at this section of the river was not intensive enough to detect rare species.

In its native range E. ischnus was found in fresh and slightly brackish waters of large tributaries of Caspian and Black Sea, but also in the littoral of the open Caspian and Black Sea. However, the taxonomic confusion about freshwater and marine forms is still not resolved (JazDzewski, 1980; Pinkster, 1993). The freshwater form, E. ischnus (s.s.) is euryhaline, primarily riverine and prefers large, slow-flowing waters with stony substrates. It was found mainly on stone or gravel substrates along the shallow margins of lakes and rivers, and the greatest densities were found in Dreissena clumps (JAZDZeWski, 1980; Kohn \& WaterstraAt, 1990; Dermott et al., 1998; Kang, 2003). At three sites along the Drava, samples were collected mostly from sand (psammal) microhabitats. Therefore, we assume that the relatively low densities of E. ischnus established in lower Drava are the consequence of the prevalence of sand and mud substrates int this section of the river. In the Danube it was only not found at the Aljmaš site, where the dominant substrate from which samples were collected was a mix of sand and mud. At two sites in Danube (Batina and Borovo) most samples were collected on artificial substrates (technolithal), while in Ilok, where sand and mud dominated, one sample was collected on small stones (microlithal). In the lower (Serbian) section of the Sava with muddy sediments, E. ischnus was found only on the large stones of embankments ( $\check{Z}_{\mathrm{GA}}$ NEC et al., unpublished). Those findings are in accordance with the well-known preference of this litophilic gammarid for stony substrates (KANG, 2003). It is very likely that much the higher densities of E. ischnus in Drava could be found on the technolithal substrate of embankments and groynes, where future sampling should be conducted. Also, due to the E. ischnus preference for Dreissena clumps, which are abundant in the middle Drava and especially in Drava reservoirs (LAJTNER et al., 2004), if it spreads further upstream it could easily became much more abundant than it is now in the lower Drava. Due to the mentioned problems with the detection of E. ischnus in the lower Drava in previous studies, it is not possible to say when exactly this species colonized Drava. We estimate that this happened probably 10-20 years ago since it has already colonized 58 $\mathrm{km}$ of the lower Drava between Osijek and Donji Miholjac. Further, we cannot say much about the speed of its upstream spreading. Therefore, further studies should check its distribution in the least studied section of the Drava between Donji Miholjac and Tere- 
zino Polje and try to establish its invasion front for future monitoring of its upstream spreading in Drava.

The species has different life histories in its native and in the invaded range (overview in KonOPACKA \& JESIONOWSKA, 1995). In its native range, the reproduction of E. ischnus takes place from March/April until October while in Polish populations it occurs from February until October. Populations in tributaries of the Don River, with a limited annual temperature range, breed throughout the year. Ovigerous females in the native range produce more eggs (Ukraine population had an average 33 and a maximum 55 eggs) than those in the invaded range (Poland: avg-10 and max-27; Germany: <20) (KoNOPACKA \& JESIONOWSKA, 1995). Populations from a fluvial lake at the confluence of the St. Lawrence and Ottawa rivers in Canada were found to have maximum brood size of only 19 eggs probably due to the low conductivity of these waters (KESTRUP \& RICCIARDI, 2010). Therefore, fecundity of E. ischnus in the invading range is relatively low, which could be expected in Drava as well. However, in spite of this, due to its repeated reproduction and small size this species co-occurs with much larger and more fecund $(D$. villosus) as well as with the more abundant (C. curvispinum) dominant invasive amphipods in lower Drava.

\section{ACKNOWLEDGMENTS}

We would like to thank Nina Jeran for linguistic improvements on an earlier version of the manuscript.

Received May 18, 2015

\section{REFERENCES}

Bij De Vaate, A., Jazdzewski, K., Ketelaars, H. A. M., Gollasch, S., \& Van Der Velde, G., 2002: Geographical patterns in range extension of Ponto-Caspian macroinvertebrate species in Europe. Canadian Journal of Fisheries and Aquatic Sciences 59, 1159-1174.

Birštejn, J. A., \& Romanova, N. N., 1968: Otrjad bokoplavy. Amphipoda. In Birštejn, J. A. (ed.), Atlas bespozvonotnych Kaspijskogo morja. Moskva: Piščevaja Promyšlennost. pp. 241-289.

Borza, P., Csányi, B., Huber, T., Leitner, P., Paunović, M., Remund, N., Szekeres, J., \& Graf, W., 2015 : Longitudinal distributional patterns of Peracarida (Crustacea, Malacostraca) in the River Danube. Fundamental and Applied Limnology 187, 113-126.

Cărăuşu, S., Dobreanu, E., \& Manolache, C., 1955: Amphipoda forme salmastre şi de apă dulce. Fauna Republ. pop. Romine, Crustacea 4, 1-407.

Cristescu, M. E. A., Witt, J. D. S., Grigorovich, I. A., Hebert, P. D. N., MacisaAc, H. J., 2004: Dispersal of the Ponto-Caspian amphipod Echinogammarus ischnus: invasion waves from the Pleistocene to the present. Heredity 92, 197-203.

Dermott, R., Mitchell, J., Murray, I., \& Fear, E., 1998: Distribution of the Ponto- Caspian amphipod Echinogammarus ischnus in the Great Lakes and replacement of native Gammarus fasciatus. Journal of Great Lakes Research 24, 442-452.

Eggers, T. O. \& Martens, A., 2001: Bestimmungsschlüssel der Süßwasser-Amphipoda (Crustacea) Deutschlands. Lauterbornia 42, 1-68.

Holdich, D. M. \& PöcKL, M., 2007: Invasive crustaceans in European inland waters. In F. GHerARdi (ed.), Biological invaders in inland waters: Profiles, distribution, and threats. Dordrecht, The Netherlands: Springer. pp. 29-75.

HrN En 16150, 2012: Water quality - Guidance on Pro rata Multi-Habitat sampling of benthic macroinvertebrates from wadeable rivers. pp.1-12.

JAZDZEWSKI, K., 1980: Range extension of some gammaridean species in European inland waters caused by human activity. Crustaceana Supplement 6, 84-107. 
KANG, M., 2003: The relationship between anthropogenic disturbance and the distribution of a nonindigenous species, Echinogammarus ischnus Stebbing, 1898 (Amphipoda: Gammaridae), at Great Lakes Coastal Margins. Doctoral Thesis, University of Windsor. pp. 1-116.

Karaman, G. S. \& Pinkster, S., 1977a: Freshwater Gammarus species from Europe, North Africa and adjacent regions of Asia (Crustacea - Amphipoda) Part I. Gammarus pulex - group and related species. Bijdragen Tot de Dierkunde 47, 1-97.

Karaman, G. S. \& Pinkster, S., 1977b: Freshwater Gammarus species from Europe, North Africa and adjacent regions of Asia (Crustacea - Amphipoda) Part II. Gammarus roeseli - group and related species. Bijdragen Tot de Dierkunde 47, 165-196.

Karaman, G. S. \& Pinkster, S., 1987: Freshwater Gammarus species from Europe, North Africa and adjecent regions of Asia (Crustacea-Amphipoda). Part III. Gammarus balcanicus-group and related species. Bijdragen Tot de Dierkunde 57, 207-260.

Karaman, S. L., 1953: Pontokaspische Amphipoden der jugoslavischen Fauna. Acta musei Macedonici scientarum naturalium 1, 21-60.

Kestrup, Å., \& Ricciardi, A., 2010: Influence of conductivity on life history traits of exotic and native amphipods in the St. Lawrence River. Fundamental and Applied Limnology / Archiv für Hydrobiologie 176, 249-262.

Köhn, J., \& WaterstraAt, A., 1990: The amphipod fauna of Lake Kummerow (Mecklenburg, German Democratic Republic) with reference to Echinogammarus ischnus Stebbing, 1899. Crustaceana 58, 74-82.

Konopacka, A., \& JesionowsKa, K., 1995: Life history of Echinogammarus ischnus (Stebbing, 1898) (Amphipoda) from artificially heated Lichenskie Lake (Poland). Crustaceana 68, 341-349.

Lajtner, J., Marušić, Z., Klobučar, G. I. V, Maguire, I., \& Erben, R., 2004: Comparative shell morphology of the zebra mussel, Dreissena polymorpha in the Drava river (Croatia ). Biologia 59, 595-600.

Paunović, M. M., Jakovčev-Todorović, D. G., Šimić, V. M., Stojanović, B. D., \& Cakić, P. D., 2007: Macroinvertebrates along the Serbian section of the Danube River (stream km 1429-925). Biologia 62, 214-221.

Paunović, M., Csányi, B., Simić, V., Đikanović, V., Petrović, A., Miljanović, B., \& Atanacković, A., 2010: Community structure of the aquatic macroinvertebrates of the Danube River and its tributaries in Serbia. In Simonović, P., Simić, V., Simić, S. \& Paunović, M. (eds.), The Danube in Serbia. The Results of National Program of the Second Joint Danube Survey 2007. pp. 183-205.

Pinkster, S., 1993: A revision of the genus Echinogammarus Stebbing, 1899 with some notes on related genera (Crustacea, Amphipoda). Memorie del Museo di Storia Naturale 10, 1-185.

PlJakić, M., 1965. Population distribution and pattern of some Pontocaspian amphipoda in the Danube. Arhiv Bioloških Nauka 17, 77-82.

Sснӧll, F., 1990: Erstnachweis von Echinogammarus ischnus Stebbing im Rhein. Lauterbornia 5, 71-74.

Van Den Brink, F. W. B., Paffen, B. G. P., Oosterbroek, F. M. J., \& Van Der Velde, G., 1993: Immigration of Echinogammarus (Stebbing, 1899) (Crustacea: Amphipoda) into The Netherlands via the lower Rhine. Bulletin of the Zoological Museum of the University of Amsterdam 13, 167-170.

Witt, J. S. D., Hebert, P. D. N., \& Morton, W. B., 1997: Echinogammarus ischnus: another crustacean invader in the Laurentian Great Lakes basin. Canadian Journal of Fisheries and Aquatic Sciences 54, 264-268.

Žganec, K., Gottstein, S., \& Hudina, S., 2009: Ponto-Caspian amphipods in Croatian large rivers. Aquatic Invasions 4, 327-335.

\title{
SAŽETAK
}

\section{Nalazi invazivnog rakušca Echinogammarus ischnus (Stebbing, 1899) u Hrvatskoj}

\author{
K. Žganec, R. Ćuk \& S. Dekić
}

Ponto-kaspijski strani i invazivni rakušac, Echinogammarus ischnus (Stebbing, 1899), pronađen je prvi puta u Hrvatskoj u Dunavu na tri postaje (Batina, Borovo i Ilok) i u donjem toku rijeke Drave. Na tri postaje u Dunavu imao je relativno malu gustoću od $4.8-6.7$ jed.m ${ }^{-2}$ 
i mali udio od 2.4-2.8\% u ukupnom broju rakušaca. Najuzvodnija postaja na kojoj je nađen u Dravi, kod mjesta Donji Miholjac, udaljena je otprilike $82 \mathrm{~km}$ od ušća u Dunav. Dvije nizvodne postaje na kojoj je nađen udaljene su 56 km (Belišće) i 24 km (Osijek) uzvodno od ušća rijeke Drave. Na postajama Osijek i Belišće zabilježen je zajedno s druge dvije invazivne vrste rakušaca Dikerogammarus villosus i Chelicorophium curvispinum, a njegov udio bio je $5 \%$ ukupnog broja rakušaca na obje postaje. Na postaji kod Donjeg Miholjca uz ove dvije strane vrste zabilježen je zajedno s još dvije autohtone vrste Gammarus fossarum i G. roeseli s relativnim udjelom od $2 \%$. Gustoća vrste na pretežno pješčanom sedimentu u Dravi smanjivala se u uzvodnom smjeru od 24 jed. $\mathrm{m}^{-2} \mathrm{u}$ Osijeku do 1.6 jed. $\mathrm{m}^{-2} \mathrm{u}$ Donjem Miholjcu. 